\title{
The long-term development of avalanche risk in settlements considering the temporal variability of damage potential
}

\author{
S. Fuchs ${ }^{1}$, M. Keiler ${ }^{2}$, A. Zischg ${ }^{3}$, and M. Bründl ${ }^{4}$ \\ ${ }^{1}$ alpS Centre for Natural Hazard Management, Innsbruck, Austria \\ ${ }^{2}$ Department of Geography and Regional Research, University of Vienna, Austria \\ ${ }^{3}$ Geo Information Management, Gargazzone, Italy \\ ${ }^{4}$ WSL Swiss Federal Institute for Snow and Avalanche Research SLF, Davos, Switzerland
}

Received: 7 September 2005 - Revised: 3 November 2005 - Accepted: 3 November 2005 - Published: 9 November 2005

Part of Special Issue "Multidisciplinary approaches in natural hazard and risk assessment"

\begin{abstract}
Recent studies on the avalanche risk in alpine settlements suggested a strong dependency of the development of risk on variations in damage potential. Based on these findings, analyses on probable maximum losses in avalanche-prone areas of the municipality of Davos $(\mathrm{CH})$ were used as an indicator for the long-term development of values at risk. Even if the results were subject to significant uncertainties, they underlined the dependency of today's risk on the historical development of land-use: Small changes in the lateral extent of endangered areas had a considerable impact on the exposure of values. In a second step, temporal variations in damage potential between 1950 and 2000 were compared in two different study areas representing typical alpine socio-economic development patterns: Davos $(\mathrm{CH})$ and Galtür (A). The resulting trends were found to be similar; the damage potential increased significantly in number and value. Thus, the development of natural risk in settlements can for a major part be attributed to long-term shifts in damage potential.
\end{abstract}

\section{Introduction}

During the last decades, compensations for damage paid out by insurance companies due to harms resulting from natural hazards increased world-wide (e.g. MunichRe, 2005a, b). A similar trend could be observed in alpine countries on a regional level, recent examples affecting settlements and threatening traffic lines include the avalanche winter 1999 and the inundations in 2000, 2002 and 2005. This development illustrates the need for a sound, precautionary and sustainable dealing with natural hazard phenomena, taking

Correspondence to: S. Fuchs

(fuchs@alps-gmbh.com) into consideration both, the processes and the values at risk (Benson and Clay, 2004; Dilley et al., 2005).

Risk resulting from natural hazards is defined as a function of the probability of a hazard process and the related extent of damage (Eq. 1). In accordance with the definition of United Nations (2004), specifications for the probability of the defined scenario $\left(p_{S i}\right)$, the value of the object affected by this scenario $\left(A_{O j}\right)$, the probability of exposure of object $j$ to scenario $i\left(p_{O j, S i}\right)$, and the vulnerability of object $j$ in dependence on scenario $i\left(v_{O j, S i}\right)$ are required for the quantification of risk $\left(R_{i, j}\right)$.

$R_{i, j}=p_{S i} \cdot A_{O j} \cdot p_{O j, S i} \cdot v_{O j, S i}$

However, until now, there have only been few studies related to the development of risk resulting from natural hazard processes over time (Wilhelm, 1997; Fuchs et al., 2004; Zischg et al., 2005a, b). An increased use of hazard-prone areas for settlement and infrastructure has been assumed to be responsible for an increased risk and resulting losses during periods of high hazard activity (see e.g. Ammann, 2001; Barbolini et al., 2002), particularly concerning avalanche hazards. Since (1) the natural avalanche activity seemed to be constant during the last 50 years (Laternser and Schneebeli, 2002) and (2) the avalanche run-out areas were reduced due to the construction of permanent mitigation structures in the release areas, this assumption could be explained by (3) longterm shifts in the damage potential. Analysing this assumption within a field study in the municipality of Davos $(\mathrm{CH})$, Fuchs et al. (2004) conclude that in general, the risk resulting from avalanche hazards decreased fundamentally since 1950 . However, high ranges occurred during the sets of calculation. Small variations in the run-out lengths of the avalanche scenarios resulted in high scattering in the risk analyses, which provides evidence for the particular influence of the damage potential on the quantification of risk. 


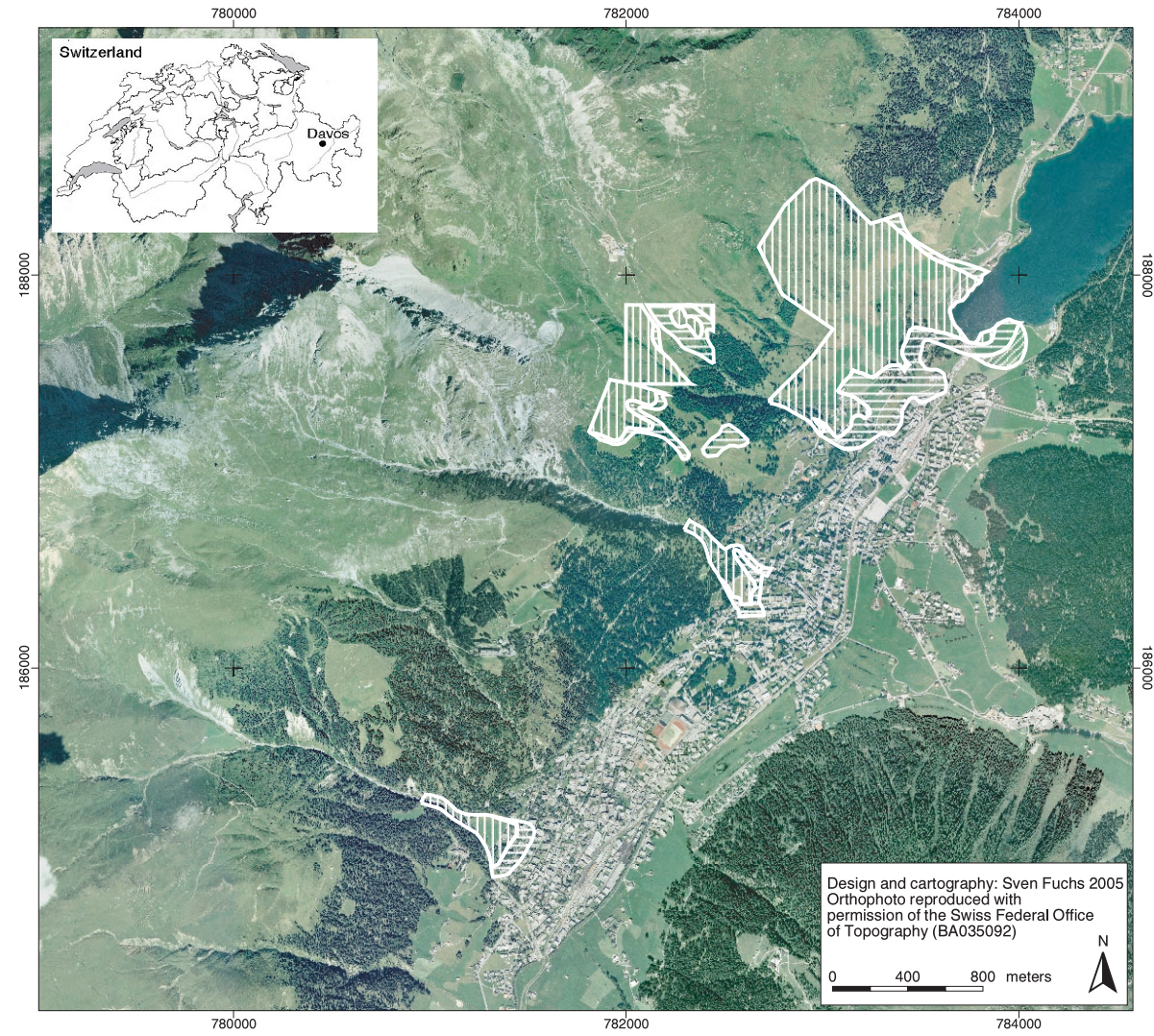

Fig. 1. Study area in the municipality of Davos. The hatched raster represents the avalanche run-out areas ( scenario $\left._{2000}\right)$. Vertical hatching corresponds to the red hazard zone (30-year scenario), horizontal hatching to the blue hazard zone (300-year scenario), and angular hatching to the yellow hazard zone (run-out area of powder snow avalanches). For explanations regarding hazard zoning in Switzerland, see the Appendix.

Table 1. Parameters distinguishing the study areas in Davos $(\mathrm{CH})$ and Galtür (A).

\begin{tabular}{lccc}
\hline & Area $\left(\mathrm{km}^{2}\right)$ & Inhabitants & Tourists \\
\hline Davos (1560 m a.s.1.) & 254 & 13000 & 45000 \\
Galtür (1580 m a.s.1.) & 121 & 770 & 4000 \\
\hline
\end{tabular}

The objective of this study is to highlight these ranges and to contribute to a discussion focusing on the significance of damage potential when carrying out long-term risk analyses related to natural hazards. The spatial sensitivity of the results is discussed. First, the development of probable maximum loss is presented for a case study carried out in Davos $(\mathrm{CH})$ related to avalanche risk. Second, the development of values at risk in the municipality of Davos $(\mathrm{CH})$ is compared to a similar study carried out in the municipality of Galtür (A). Both municipalities represent typical alpine villages dependent on winter tourism, thus, the results mirror recent developments in damage potential in alpine destinations.

The municipality of Davos is the largest municipality in the canton of Grisons in Switzerland (Fig. 1) and covers an area of $254 \mathrm{~km}^{2}$. In 2000, approximately 13000 inhabitants lived in Davos, and up to 45000 tourists were present during winter time (BfS, 2001, see Table 1). The altitude of the city centre is situated at $1560 \mathrm{~m}$ a.s.1., which illustrates its susceptibility to avalanche hazards. The centre of Davos is exposed to four main avalanche paths which are almost completely equipped with snow supporting structures in the release areas.

The municipality of Galtür is located $50 \mathrm{~km}$ north-east of Davos in Tyrol, Austria, at an altitude of $1580 \mathrm{~m}$ a.s.1. The municipality covers an area of $121 \mathrm{~km}^{2}$ and 770 inhabitants lived there in the year 2000 (Landesstatistik Tirol, 2004, see Table 1). During winter time, up to 4000 additional persons were counted living in the hotels and guest houses of the village (Gemeinde Galtür, 2003). Galtür is endangered by 26 avalanche paths, nine of which are equipped with defence structures in the starting zone. Major avalanche dams protecting the centre of Galtür were constructed after the avalanche event of 1999 .

\section{Development of probable maximum loss in Davos}

This study aims to contribute to the discussion on development of risk over time. It focuses on the relative comparison 
of different system conditions resulting from socio-economic changes in alpine environments. The probable maximum loss (PML) resulting from avalanches in the year 1950 was compared to the remaining PML in 2000, considering technical mitigation measures implemented during the same period. Establishing the PML determines the upper boundary of risk related to a worst-case scenario. This originally actuarial approach identifies the largest potentially assumable loss. To calculate the PML, according to Equation 1, data related to the process and to the values at risk are needed.

\subsection{Methods}

Changes in the extent of the avalanche accumulation areas were studied using the numerical avalanche model AVAL1D (e.g. Christen et al., 2002a) in combination with the avalanche incident cadastre of former events. AVAL-1D is a one-dimensional avalanche dynamics program for the prediction of run-out distances, flow velocities and impact pressure of both dense flow and powder snow avalanches. The dense flow simulation is based on a Voellmy-fluid flow law, while the powder snow simulation follows Norem's description of powder flow avalanche formation and structure (Norem, 1995). The avalanche calculation is based on a dryCoulomb type friction $(\mu)$ and a velocity squared friction $(\xi)$ and was carried out following the guidelines given in the manual (Christen et al., 2002b). The fracture depths were obtained using Gumbel's extreme value statistics on the possible maximum new snow heights within three days. The input parameters were calibrated on the basis of the legal hazard map.

The values at risk were obtained analysing the zoning plan, which was provided by the municipal administration of Davos. This plan contains detailed information about the location and perimeter of every building. Additional information, such as year of construction, type and replacement value were provided by the land registry office and analysed using GIS. The number of endangered permanent residents was derived from the number of domiciles. Statistics indicated 3.6 persons per unit in the year 1950 and 2.4 per unit in the year 2000 (Ritzmann-Blickenstorfer, 1996; BfS, 2001). The number of exposed persons in hotels, guest houses and hospitals was quantified by the number of beds, multiplied by the degree of utilisation. To account for the employees working in hotels and hospitals the number of beds was increased by 20\% (Davos Tourist Board 2002, pers. comm.) and $70 \%$ (BfS, 2002), respectively.

The vulnerability of buildings and persons as well as their probability of presence was considered in terms of PML, which traces back to actuarial procedures and is the largest potentially assumable loss. Following these ideas, the total avalanche run-out areas were considered when calculating the values at risk. The cumulative PML for the areas endangered by avalanches in the year 1950 was compared to the year 2000: First, the values at risk were quantified for the year 1950. Second, the values at risk for the year 2000 were calculated under consideration of a reduction of the run-out areas due to the construction of permanent mitigation structures, such as snow fences in the avalanche starting zones. The development of PML resulted from the comparison between the initial state in the year 1950 and the state in the year 2000, including the aggregation and expansion of values at risk during the same period.

The modelling of avalanche scenarios is affected by uncertainties resulting from model parameters on the one hand and from input parameters on the other hand. Following a suggestion outlined in Barbolini et al. (2002), the range resulting from those uncertainties was calculated on the basis of a confidence interval of $95 \%$. Thus, as an example, the $30-$ year event was calculated with a range in the run-out length of $\pm 20 \mathrm{~m}$, and the 300-year event with a range of $\pm 30 \mathrm{~m}$.

\subsection{Results}

Based on the methods outlined above, the PML in areas affected by avalanches was determined for the municipality of Davos. The result section focuses on the relatively frequent event of a 30-year avalanche scenario and the relatively rare event of a 300-year avalanche scenario because these scenarios represent the outline of the red and blue hazard zone in Switzerland (see the Appendix), and they represent the typical problems when dealing with design events in the area of risk analyses resulting from alpine hazards. Thus, emerging problems could be well demonstrated.

In the year 1950, 83 buildings with a total replacement value of approximately EUR 107.6 million had been located inside the run-out areas affected by a 30-year avalanche scenario (Fig. 2, Table 2). In the year 2000, 33 buildings with a replacement value of EUR 19.3 million were situated inside the area affected by a 30-year avalanche, which is nearly $40 \%$ in number and $18 \%$ in value of the 1950 s calculation. The endangered residential population amounted to 591 persons living in the area of a 30-year avalanche run-out zone in 1950. In 2000, in consequence of the construction of permanent mitigation measures, 87 residents remained exposed, which is an $85 \%$ reduction of PML. However, the range of these results was considerable: Inside the areas of a 30-year avalanche event, the number of buildings scattered almost $25 \%$ in number and value for the scenario 1950 and $50 \%$ for the scenario 2000. Concerning residential population, the values ranged from $\pm 20 \%$ for the scenario 1950 to a remarkable factor of around $450 \%$ for the scenario 2000. Generally, the PML inside areas affected by a 30-year avalanche decreased regarding the exact values as well as the minimum and maximum values for the number and value of endangered buildings and for the number of affected persons. Compared to the results of the 300-year avalanche scenario, those values were relatively small.

Inside areas affected by the 300-year avalanche scenarios, a total of 161 buildings with a replacement value of almost EUR 240 million were located in the year 1950 (Fig. 2, Table 2). In the year 2000, an amount of 125 buildings with a total value of almost EUR 122 million remained endangered, including 28 buildings that had been constructed in the pe- 

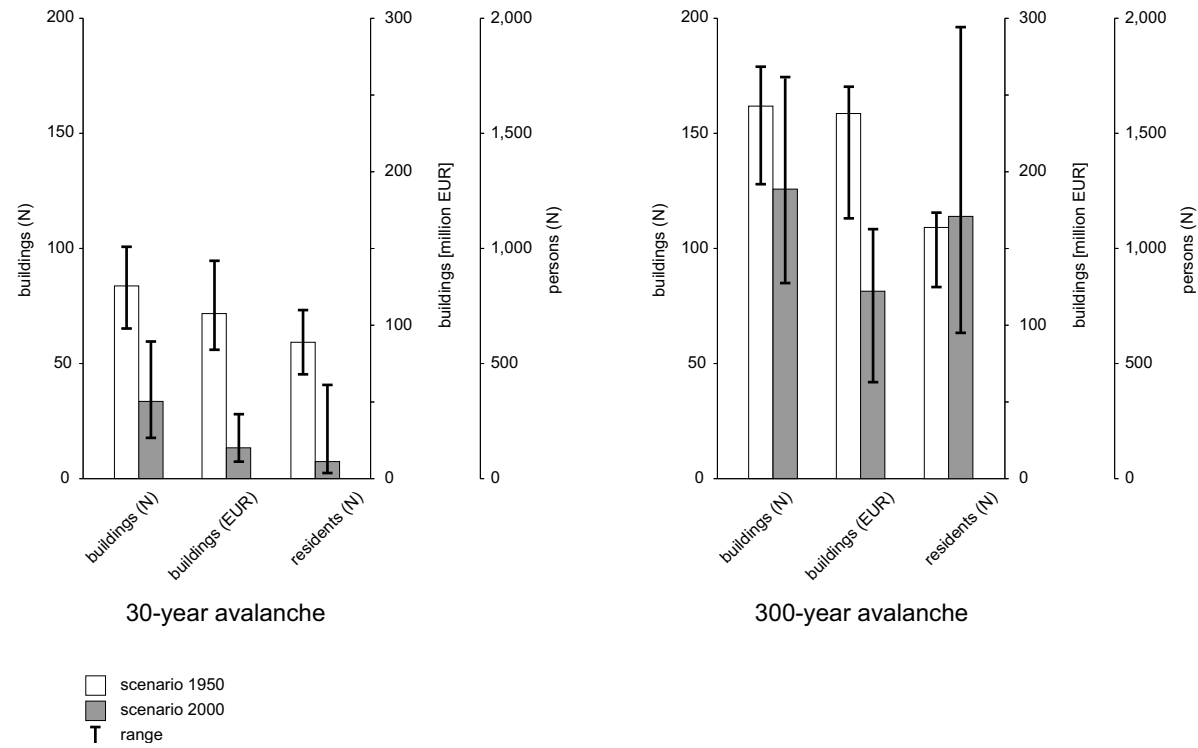

Fig. 2. Scenario 1950 and scenario 2000 resulting from 30-year and 300-year avalanche events in the municipality of Davos (CH), and associated uncertainties following the suggestions outlined in Barbolini et al. (2002). For the 30-year scenario, the ranges regarding the buildings are relatively similar, while the range resulting from the residents in the year 2000 is remarkably high. For the 300 -year scenario in the year 2000 , the highest range occurred within the category of endangered residential population, while the lowest variations were found for the number of buildings.

Table 2. Probable maximum loss in Davos related to the 30- and the 300-year scenario.

\begin{tabular}{lcccccc}
\hline & \multicolumn{2}{c}{1950} & \multicolumn{2}{c}{2000} \\
& \multicolumn{2}{c}{ Buildings } & Residents & \multicolumn{2}{c}{ Buildings } & Residents \\
& $\mathrm{N}$ & M EUR & $\mathrm{N}$ & $\mathrm{N}$ & M EUR & $\mathrm{N}$ \\
\hline 30-year scenario & 83 & 107.6 & 591 & 33 & 19.3 & 87 \\
300-year scenario & 161 & 239.4 & 1098 & 125 & 121.8 & 1137 \\
\hline
\end{tabular}

riod before 1950 and 97 buildings that were constructed between 1951 and 2000. Thus, the 2000s results correspond to almost $78 \%$ in number and around $50 \%$ in value of the 1950 s calculation. Inside the areas of the 300-year avalanche scenarios, 1098 residents lived in the year 1950. In the year 2000, this value increased slightly to 1137 persons. In comparison to the areas affected by the 30 -year avalanche scenarios, the range - in absolute numbers - is significantly higher. Regarding the 300-year avalanche events, the values of the scenario 2000 scattered remarkably higher than those of the scenario 1950. The highest range was found in the category of residents for the scenario 2000, were the number ranged from 636 to 1971 persons. Particularly in the category of residential population it became evident that the range of the scenarios was higher than the difference between the scenario 1950 and the scenario 2000.

Regarding temporal population in hotels, guest houses and hospitals, the 1950s scenario of the 300-year avalanche events included 1041 guest beds in accommodation facilities and 1851 beds in hospitals. Applying an average rate of utilisation of $60 \%$ (Davos Tourist Board 2002, pers. comm.) to hotels and $83.7 \%$ to hospitals (Kurverein Davos, 1951), 625 guests in accommodation facilities and 1550 patients in hospitals remained vulnerable. Including labour force, these numbers account to 750 persons and 2590 persons, respectively. In the year 2000, 81 guests remained in the category of hotels and guest houses. Assuming an utilisation of $60 \%$ during the winter season and including employees, 59 persons were endangered. Hospitals were no longer endangered.

\subsection{Conclusions}

In the previous sections, the development of PML between 1950 and 2000 was presented for the municipality of Davos $(\mathrm{CH})$. Based on the assumptions outlined in the methods section, the PML decreased remarkably for both, areas affected by 30-year avalanches and areas affected by 300-year avalanches. The sole exception was in the category of residents within the 300-year scenario, where an increase in PML was verifiable. The associated range was considerable, resulting from a dense utilisation of development land in the studied area. Small variations in the extent of the ac- 
cumulation areas $( \pm 20 \mathrm{~m}$ for the 30-year avalanche events and $\pm 30 \mathrm{~m}$ for the 300 -year avalanche events) demonstrated a significant importance of the temporal and spatial analysis of values at risk.

The investigation provides specific information regarding the development of avalanche risk in the municipality of Davos $(\mathrm{CH})$, based on analyses of PML. General statements referring to a larger area (canton, country) might be difficult to deduce, since small-scale land-use disparities have a significant influence on the diversification of risk. The spatial distribution of damage potential is substantially influenced by the historical growth of settlements on the one hand and spatial planning issues on the other hand. When analysing the development plan, this could be proven by relatively larger buildings downwards the slope and smaller buildings upwards the slope, representing the respective buildings codes and the underlying admissible floor space indices.

In addition to the described range of the results from the analyses on PML, several inherent uncertainties regarding the application of the risk equation (Eq. 1) should be considered when analysing risk over time:

1. Regarding the probability of presence $\left(p_{O j, S i}\right)$ of endangered persons, the question is how to determine their number at the specific time of occurrence of an avalanche event. The permanent residential population could be empirically determined using the average number of persons per domicile. The temporally variable number of persons in hotels and hospitals could be approximated using the number of beds and the corresponding average utilisation. Concerning infrastructure facilities, such as buildings of the public sector or cable car stations, such statistics are for the most part not available. Thus, high uncertainties should be taken into consideration when assessing the probability of presence of endangered persons, or the calculation should be a priori carried out using a value in terms of an upper limit. Furthermore, the spatial probability of presence is subject to considerable temporal changes, as presented by Keiler et al. (2005).

2. Further uncertainties are connected to the vulnerability factor $\left(v_{O j, S i}\right)$. Concerning the vulnerability of buildings towards the impacts of avalanches, consolidated findings allowing for a spatial application are still missing (IUGS, 1997; Jónasson et al., 1999; Keylock and Barbolini, 2001). Assumptions, as for example presented in Wilhelm (1997), can only partly contribute to this problem. Future research is needed to obtain significant empirical data on the relevant parameters for the determination of the vulnerability of buildings.

3. Moreover, future research concerning the behaviour of avalanches in the accumulation areas is needed, especially related to the structure of buildings. Buildings can have similar effects on avalanches as avalanche retarding mounds. Due to a shift in the building pattern within the accumulation area, buildings oriented towards the valley bottom tend to result in smaller risk than buildings that are located closer towards the transit area. Independently from the related political implications and the associated impacts on land-use planning, further investigations on this effect should be carried out, because of the probable reduction of the accumulation areas and, as a consequence, the resulting risk.

Independent from these methodical restrictions resulting from the application of the risk equation (Eq. 1), trends arising from the shifts in damage potential should be taken into consideration, leading to an enhanced understanding of the long-term development of risk in settlements.

\section{Development of damage potential in Davos and Galtür}

Apart from today's land-use regulations and the associated legal fundamentals, land utilisation and building development is based on historical settlement growth and resulting land-use patterns. For this reason, detailed studies on the spatial distribution of values at risk are major issues in dealing with risk, particularly for tourism-dependent municipalities, as stated in Keiler (2004) for the municipality of Galtür (A) and Fuchs and Bründl (2005) for the municipality of Davos $(\mathrm{CH})$. However, only few approaches and conceptual proposals describe the determination of damage potential, focusing more on fatalities and direct damage cost of specific events than on methodological issues. Related to settlements, early studies by Björnsson (1980) and more recent studies by Glade and Crozier (1996), Jóhannesson and Arnalds (2001), Stethem et al. (2003), Kleist et al. (2004) and Merz et al. (2004), have to be mentioned.

Due to the lack of comparative studies, additional analyses concerning the temporal development of damage potential have been carried out in the municipality of Galtür (Keiler, 2004). Results from both of the municipalities based on areas affected by avalanches are presented in the following sections. Focusing on emerging trends in the development of damage potential, the comparative study deliberately neglects different legal land-use and planning regulations in the two alpine countries.

\subsection{Values at risk in Davos}

The number and value of buildings in the studied area rose considerably between 1950 and 2000 (Fig. 3, Table 3). The total number of buildings has almost tripled, from 161 in 1950 to 462 in 2000. This increase was due to the shift from 51 to 256 in the category of residential buildings, while in the other categories of buildings the number of buildings was approximately unchanging. A significant increase in number dated back in the 1960s and 1970s before the legally hazard map came into force (Fuchs and Bründl, 2005).

The total value of buildings increased by a factor of almost four. In 1950, the total sum of insured buildings was EUR 240 million and in 2000, the total sum was EUR 930 million. 

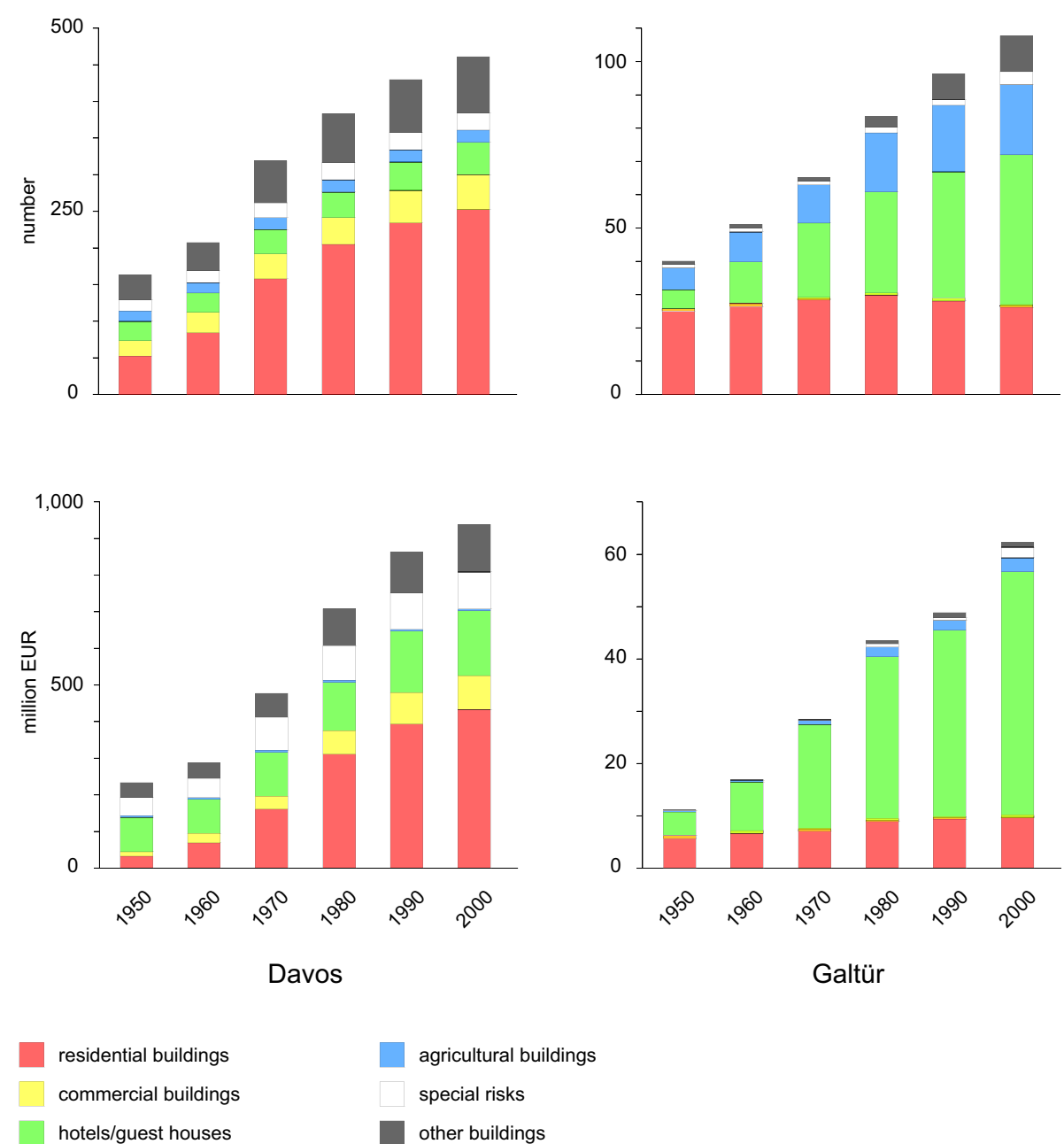

agricultural buildings

special risks

other buildings

Fig. 3. Development of damage potential in Davos $(\mathrm{CH})$ and Galtür $(\mathrm{A})$ related to the respective avalanche-prone areas, subdivided in decades and building functions.

Table 3. Values at risk in Davos.

\begin{tabular}{|c|c|c|c|c|c|c|c|c|c|c|c|c|}
\hline \multirow[b]{2}{*}{ Building categories } & \multicolumn{2}{|c|}{1950} & \multicolumn{2}{|c|}{1960} & \multicolumn{2}{|c|}{1970} & \multicolumn{2}{|c|}{1980} & \multicolumn{2}{|c|}{1990} & \multicolumn{2}{|c|}{2000} \\
\hline & $\mathrm{N}$ & k EUR & $\mathrm{N}$ & k EUR & $\mathrm{N}$ & k EUR & $\mathrm{N}$ & k EUR & $\mathrm{N}$ & k EUR & $\mathrm{N}$ & k EUR \\
\hline Residential & 51 & 34980 & 85 & 62145 & 158 & 160951 & 206 & 312127 & 236 & 385881 & 256 & 428972 \\
\hline Agricultural & 13 & 4589 & 13 & 4589 & 16 & 5166 & 16 & 5166 & 16 & 5166 & 16 & 5166 \\
\hline Special risk & 14 & 46833 & 16 & 48393 & 20 & 87199 & 22 & 95457 & 23 & 99611 & 24 & 100229 \\
\hline Commercial & 22 & 17594 & 28 & 26209 & 33 & 38359 & 38 & 65586 & 43 & 82507 & 47 & 91361 \\
\hline Hotels and guest houses & 27 & 93768 & 27 & 93768 & 32 & 121246 & 35 & 134608 & 39 & 163857 & 43 & 175062 \\
\hline Others & 34 & 41668 & 39 & 43474 & 58 & 66344 & 66 & 102462 & 71 & 111160 & 76 & 127360 \\
\hline Sum & 161 & 239432 & 208 & 278578 & 317 & 479265 & 383 & 715406 & 428 & 848182 & 462 & 928150 \\
\hline
\end{tabular}

In 1950, the proportion of residential buildings was less than $15 \%$, compared to the total amount of endangered buildings. Until 2000, this ratio changed to almost 50\%. Regarding the category of hotels and guest houses as well as the category of special risks, nearly no increase in value could be observed. However, those categories showed a higher average value per building than residential buildings.
The number of endangered persons increased slightly. In 1950, a permanent residential population of 1098 persons was exposed to avalanche hazards, until 2000 this value increased to 1137 persons. This is a relatively moderate increase of $3.6 \%$, compared to the increase in tangible assets. If the classification into different building functions is carried out, this increase turned out to be larger. In residential build- 
Table 4. Values at risk in Galtür.

\begin{tabular}{|c|c|c|c|c|c|c|c|c|c|c|c|c|}
\hline \multirow[b]{2}{*}{ Building categories } & \multicolumn{2}{|c|}{1950} & \multicolumn{2}{|c|}{1960} & \multicolumn{2}{|c|}{1970} & \multicolumn{2}{|c|}{1980} & \multicolumn{2}{|c|}{1990} & \multicolumn{2}{|c|}{2000} \\
\hline & $\mathrm{N}$ & k EUR & $\mathrm{N}$ & k EUR & $\mathrm{N}$ & $\mathrm{k}$ EUR & $\mathrm{N}$ & k EUR & $\mathrm{N}$ & k EUR & $\mathrm{N}$ & k EUR \\
\hline Residential & 26 & 6585 & 28 & 7464 & 29 & 7918 & 30 & 9111 & 28 & 9783 & 27 & 9858 \\
\hline Agricultural & 7 & 583 & 9 & 884 & 12 & 1380 & 17 & 2257 & 20 & 2651 & 21 & 2896 \\
\hline Special risk & 1 & 30 & 1 & 30 & 1 & 30 & 2 & 69 & 2 & 69 & 4 & 2336 \\
\hline Commercial & 0 & 0 & 0 & 0 & 0 & 0 & 0 & 0 & 0 & 0 & 0 & 0 \\
\hline Hotels and guest houses & 6 & 4712 & 12 & 9463 & 23 & 19892 & 31 & 32963 & 37 & 35928 & 45 & 47716 \\
\hline Others & 1 & 66 & 1 & 156 & 1 & 90 & 3 & 470 & 8 & 861 & 11 & 1195 \\
\hline Sum & 41 & 11978 & 51 & 17999 & 66 & 29313 & 83 & 44872 & 95 & 49293 & 108 & 64003 \\
\hline
\end{tabular}

ings, 673 persons were concerned in 1950 and 1116 in 2000, which is an increase of two thirds. Subdividing the utilisation within the winter season into months, it became evident that the peaks in utilisation were during the Christmas period and towards the end of February. According to the analysis of the avalanche bulletin of the Swiss Federal Institute of Snow and Avalanche Research SLF, these periods coincided exactly with periods when there was an above-average occurrence of days with high avalanche danger. As a result, temporal risk peaks may possibly arise, as described in Fuchs et al. (2004).

\subsection{Values at risk in Galtür}

The values at risk were determined based on methods outlined in Keiler (2004). The total number of buildings inside avalanche-prone areas in the municipality of Galtür rose by a factor of 2.5 (Fig. 3, Table 4), from 41 in 1950 to 108 in 2000. This increase is due to the relative development in the category of hotels and guest houses, and - obviously less important - in the category of agricultural buildings. The number of buildings in all other categories stayed nearly constant. The decrease in the number of residential buildings since 1980 resulted from a modification of buildings formerly used for habitation to accommodation facilities subsequently used for tourism.

The total value of buildings rose by a factor of almost six. In 1950, the total value of buildings amounted to EUR 12 million and in 2000 to EUR 64 million. Since the 1960s, the category of hotels and guest houses held the highest proportion of the total amount of endangered values per decade and per category. In 1950, the proportion of hotels and guest houses was about $30 \%$, compared to the total value of buildings. In 2000 , this ratio changed to approximately $75 \%$. In contrast, the number and value of residential buildings showed nearly no change between 1950 and 2000. Generally, the number of buildings in the community of Galtür has risen above average in comparison to the district of Landeck and the federal state of Tyrol. In 2000, a quarter of the total value of all buildings in the municipality was found to be located in the avalanche-prone areas. The proportional increase in the value of buildings was significantly higher than the proportional increase in the number of buildings. Buildings inside avalanche-prone areas showed a lower average value as buildings outside those areas. These findings were in accordance to similar results for the community of Davos.

The number of endangered persons increased substantially. In Galtür, in 1950, approximately 850 persons were located inside exposed areas, consisting of 460 residents and 390 tourists. Until the year 2000, this value increased to 4700 persons, 770 of which were residents and 3930 were tourists. The increase in residential population was about $60 \%$, while the increase in temporal population was a factor of ten. Thus, considerable diurnal risk peaks might occur, as presented in Keiler et al. (2005).

\section{Discussion}

The results of an analysis of damage potential in Davos $(\mathrm{CH})$ and Galtür (A) suggested a similar trend, even if the community of Galtur and the community of Davos have different historical roots. Both municipalities have undergone significant socio-economic changes during the 20th century. While Davos was transformed into a winter sports destination from a traditional health resort, Galtür developed from a farming village to a centre of sustainable winter tourism. Since 1950, a significant change in the number and value of buildings has taken place in both studied municipalities, and, as a consequence, a remarkable increase was detectable in residential and temporal population. Endangered areas were increasingly protected by technical mitigation measures since the 1950s (Davos) and 1960s (Galtür). Parallel to those technical tools, spatial planning instruments were introduced. At the same time, governmental authorities in Switzerland (Frutiger, 1980) and in Austria (Bergthaler, 1975) were founded to organise protection against natural hazards.

In Davos, the increase in damage potential was caused by a significant increase in the category of residential buildings, while in Galtür this increase could mainly be attributed to an increase in accommodation facilities. These results can be attributed to (1) the different socio-economic development of the municipalities and (2) the different legal situations in 
Switzerland and Austria. While in Austria, the construction of secondary residences was restricted by law until the late 1990s, no such restrictions could be found in the canton of Grisons, Switzerland. In both municipalities, the highest increase in number and value was spatially located at the outer boundary of the endangered areas. These findings are also represented by the high range shown in Fig. 2 for the municipality of Davos. Thus, relatively small variations in the lateral extent of the areas affected by avalanches have a high impact on the values at risk. For this reason, a possible improvement in the delimitation of areas affected by natural hazard processes regarding a decrease of objects at risk could possibly be implemented using a fringe instead of a line.

Temporal changes in risk can primarily be attributed to the outlined spatiotemporal variations in damage potential. The analysis of tangible assets as well as intangibles is a quantitative procedure for comparative studies in different regions and for different hazard processes. Thus, risk analyses should consider those alternations by expanding the today's procedures by appropriate methodical approaches as well as practical implementations.

The long-term trend in the development of damage potential described above is superposed by a short-term fluctuation resulting from diurnal peaks in values at risk, particularly consisting of persons commuting to and from tourist destinations. The combination of those two phenomena should be carefully observed and integrated in the methodology of risk analyses, as shown by Keiler et al. (2005) for the community of Galtür. Similar problems related to road networks are discussed in Margreth et al. (2003) and Zischg et al. (2005a, b). In dealing with natural hazards in a proactive manner, this aspect should be strengthened and incorporated into the respective legal fundamentals.

Land use planning activities such as hazard maps are based on the concept of recurrence intervals of hazard processes. The remarkable increase of values at risk in the fringe of the endangered areas would result in a significant shift in monetary losses (and presumably fatalities) if the design event is exceeded. Due to the damage in the avalanche winter 1999, the delimitation of endangered areas is based on modified avalanche pressures in Austria. These modifications in principle represent a change of the considered design events. Similar developments might be discussed in the aftermath of the 2005 inundations in the Alps. Thus, future research is needed to quantify the impact of such modifications on (1) the result of risk analyses, (2) the assessment of risk in the cycle of integrated risk management, (3) the adjustment of coping strategies, and (4) the perception of risk by all parties involved, including policy makers.

\section{Appendix}

It is the responsibility of the Swiss cantons to protect people's life and property from natural hazards such as avalanches, landslides, erosion and rockfall in accordance with the Federal Law of 22 June 1979 relating to land-use planning. Fur- ther implementation instructions result from the appropriate articles in the Federal Law of 4 October 1991 relating to forests and the Federal Law of 21 June 1991 relating to hydraulic engineering. According to these laws and associated decrees, the appropriate specialised offices of the federal authorities have to compile guidelines to encourage the consideration of natural hazards in land-use planning. The principles for general planning issues are published in Heinimann et al. (1998), whereas the Guidelines for the Consideration of the Avalanche Danger in Land-Use Planning Activities have been approved in 1984 (BFF and SLF, 1984). These guidelines describe the two main instruments for the inclusion of avalanche danger in land-use planning, namely avalanche incident documentation and the avalanche hazard map. This hazard map divides an examined area into different subsections with different danger levels according to the severity and the likelihood of potential avalanche hazards (BFF and SLF, 1984).

Red indicates areas where pressure from avalanches with recurrence intervals $T$ between 30 and 300 years exceeds a lower limit that ranges from $3 \mathrm{kPa}$ for $T=30$ years to $30 \mathrm{kPa}$ at $T=300$ years. The entire area affected by (dense flow) avalanches with $T<30$ years is also marked in red.

Blue indicates areas where pressure from avalanches with recurrence intervals $T$ between 30 and 300 years falls below $30 \mathrm{kPa}$. Areas affected by powder avalanches with reoccurrence intervals $T<30$ years and a pressure $<3 \mathrm{kPa}$ are also marked in blue.

The run-out areas of powder avalanches with reoccurrence intervals $T>30$ years and a pressure $<3 \mathrm{kPa}$ are marked in yellow, as well as theoretically not excludable but extremely rare avalanches with a reoccurrence interval $T>300$ years.

Acknowledgements. For valuable discussion, continuing support and the supply of data, the authors want to thank M. Fischer, GVA building insurance Grisons $(\mathrm{CH}), \mathrm{K}$. Walser and the community of Galtür (A), and C. Wilhelm, Forestry Office of Grisons (CH). The study related to the development of avalanche risk in Davos was financed by WSL Swiss Federal Institute for Snow and Avalanche Research SLF. The studies were supported by grants offered by MunichRe Reinsurance Company.

Edited by: H. Stötter

Reviewed by: one referee

\section{References}

Ammann, W.: Integrales Risikomanagement - der gemeinsame Weg in die Zukunft, Bündnerwald, 5, 14-17, 2001.

Barbolini, M., Natale, L., and Savi, F.: Effects on release conditions uncertainty on avalanche hazard mapping, Nat. Haz., 25, 225244, 2002.

Benson, C., and Clay, E.: Understanding the economic and financial impacts of natural disasters, Washington, The World Bank, 2004.

Bergthaler, J: Grundsätze zur Erarbeitung von Gefahrenzonenplänen in Wildbächen der Nördlichen Kalkalpen und der Grauwackenzone, Österr. Wasserwirtschaft, 27, 160-168, 1975.

BFF and SLF: Richtlinien zur Berücksichtigung der Lawinengefahr bei raumwirksamen Tätigkeiten, Davos and Bern, Bundesamt für 
Forstwesen, Eidgenössisches Institut für Schnee- und Lawinenforschung, 1984.

BfS (ed.): Statistisches Jahrbuch der Schweiz 2001, Zürich, Verlag NZZ, 2001

BfS (ed.): Krankenhausstatistik, http://www.bfs.admin.ch/content/ bfs/portal/de/index/themen/gesundheit/gesundheitsversorgung/ einrichtungen/analysen__berichte/stand/01.html, (access 20 July 2005), 2002.

Björnsson, H.: Avalanche activity in Iceland, climatic conditions, and terrain features, J. Glaciol., 26, 13-23, 1980.

Christen, M., Bartelt, P. and Gruber, U.: AVAL-1D: An avalanche dynamics program for the practice, Proceedings Interpraevent 2002 in the Pacific Rim - Matsumoto, 14-18 October 2002, 2, 715-725, 2002a.

Christen, M., Bartelt, P. and Gruber, U.: AVAL-1D, Numerische Berechnung von Fliess- und Staublawinen, Manual zur Software, Eidgenössisches Institut für Schnee- und Lawinenforschung, Davos, 2002b.

Dilley, M., Chen, R., Deichmann, U., Lerner-Lam, A., and Arnold, M.: Natural disasters hotspots, a global risk analysis, Washington, The World Bank, 2005.

Frutiger, H.: Rechtliche Aspekte der Nutzungsbeschränkung des Grundeigentums wegen Lawinengefährdung, Proc. Internationales Sympos. Interpraevent - Bad Ischl, Austria, 8-12 September 1980, 1, 33-48, 1980.

Fuchs, S., Bründl, M., and Stötter, J.: Development of avalanche risk between 1950 and 2000 in the municipality of Davos, Switzerland, Nat. Hazards Earth Syst. Sci., 4, 263-275, 2004

\section{SRef-ID: 1684-9981/nhess/2004-4-263.}

Fuchs, S., and Bründl, M.: Damage potential and losses resulting from snow avalanches in settlements in the Canton of Grisons, Switzerland, Nat. Haz., 34, 53-69, 2005.

Gemeinde Galtür: Bettenauslastung, http://www.galtuer.gv.at/ betten.htm (access July 20, 2005), 2003.

Glade, T., and Crozier, M.: Towards a national landslide information base for New Zealand, New Zealand Geographer, 52, 29-40, 1996.

Heinimann, H., Hollenstein, K., Kienholz, H., Krummenacher, B., and Mani, P.: Methoden zur Analyse und Bewertung von Naturgefahren, Bern, BUWAL, 1998.

IUGS: Quantitative risk assessment for slopes and landslides the state of the art, in: Landslide Risk Assessment, edited by: Cruden, D. and Fell, R., Proc. of the International Workshop on Landslide Risk Assessment - Honolulu, Hawaii, USA, 19-21 February 1997, Rotterdam, 3-12, 1997.

Jóhannesson, T. and Arnalds, T.: Accidents and economic damage due to snow avalanches and landslides in Iceland, Jökull, 50, 8194, 2001.

Jónasson, K., Sigurdsson, S., and Arnalds, T.: Estimation of avalanche risk, Icelandic Meteorological Office, Reykjavik, VÍR99001-ÚR01, 1999.

Keiler, M.: Development of the damage potential resulting from avalanche risk in the period 1950-2000, case study Galtür, Nat. Hazards Earth Syst. Sci., 4, 249-256, 2004,

SRef-ID: 1684-9981/nhess/2004-4-249.
Keiler, M., Zischg, A., Fuchs, S., Hama, M., and Stötter, J.: Avalanche related damage potential - changes of persons and mobile values since the mid-twentieth century, case study Galtür, Nat. Hazards Earth Syst. Sci., 5, 49-58, 2005,

SRef-ID: 1684-9981/nhess/2005-5-49.

Keylock, C, and Barbolini, M.: Snow avalanche impact pressure vulnerability relations for use in risk assessment, Can. Geotech. J., 38, 227-238, 2001.

Kleist, L., Thieken, A., Köhler, P., Müller, M., Seifert, I., and Werner, U.: Estimation of building values as a basis for a comparative risk assessment, in: Disasters and society, edited by: Mahlzahn, D. and Plapp, T., Berlin, logos, 115-122, 2004.

Kurverein Davos: Geschäftsbericht 1950/1951, Davos, Kurverein, 1951.

Landesstatistik Tirol: Tourismus, http://www.tirol.gv.at/themen/ zahlenundfakten/statistik/tourismus.shtml (access 20 July 2005), 2003.

Landesstatistik Tirol: Landesstatistik Tirol, http://www.tirol.gv.at/ themen/zahlenundfakten/statistik/wohnbevoelkerung.shtml (access 20 July 2005), 2004.

Laternser, M. and Schneebeli, M.: Temporal trend and spatial distribution of avalanche activity during the last 50 years in Switzerland, Nat. Haz., 27, 201-230, 2002.

Margreth, S., Stoffel, L., and Wilhelm, C.: Winter opening of high alpine pass roads - analysis and case studies from the Swiss Alps, Cold Reg. Sc. Tech., 37, 467-482, 2003.

Merz, B., Kreibich, H. Thieken, A., and Schmidtke, R.: Estimation uncertainty of direct monetary flood damage to buildings, Nat. Hazards Earth Syst. Sci., 4, 153-163, 2004,

SRef-ID: 1684-9981/nhess/2004-4-153.

MunichRe: Wetterkatastrophen und Klimawandel: Sind wir noch zu retten?, München, Munich Reinsurance Company, 2005a.

MunichRe: Topics Geo - annual review: natural catastrophes 2004, München, Munich Reinsurance Company, 2005b.

Norem, H.: Shear stresses and boundary layers in snow avalanches, NGI Technical Report 581240-3, Oslo, Norwegian Geotechnical Institute, 1995.

Ritzmann-Blickenstorfer, H.: Historische Statistik der Schweiz, Zürich, Chronos, 1996.

Stethem, C., Jamieson, B., Schaerer, P., Liverman, D., Germain, D. and Walker, S.: Snow avalanche hazard in Canada - a review, Nat. Haz., 28, 487-515, 2003.

United Nations: Living with risk, Geneva, United Nations, 2004.

Wilhelm, C.: Wirtschaftlichkeit im Lawinenschutz, edited by SLF Eidgenössisches Institut für Schnee- und Lawinenforschung, Mtt. 54, Davos, 1997.

Zischg, A., Fuchs, S., Keiler, M., and Meiß1 G.: Modelling the system behaviour of wet snow avalanches using an expert system approach for risk management on high alpine traffic roads, Nat. Hazards Earth Syst. Sci., 5, 821-832, 2005a,

SRef-ID: 1684-9981/nhess/2005-5-821.

Zischg, A., Fuchs, S., Keiler, M., and Stötter, J.: Temporal variability of damage potential on roads as a conceptual contribution towards a short-term avalanche risk simulation, Nat. Hazards Earth Syst. Sci., 5, 235-242, 2005b,

SRef-ID: 1684-9981/nhess/2005-5-235. 